\title{
MICKIEWICZA ZEGAREK I PIECZĘĆ
}

\author{
JAN ZIELIŃSKI
}

Wydział Nauk Humanistycznych UKSW

Faculty of Humanities, Cardinal Stefan Wyszyński University in Warsaw

zielinski@gmx.ch

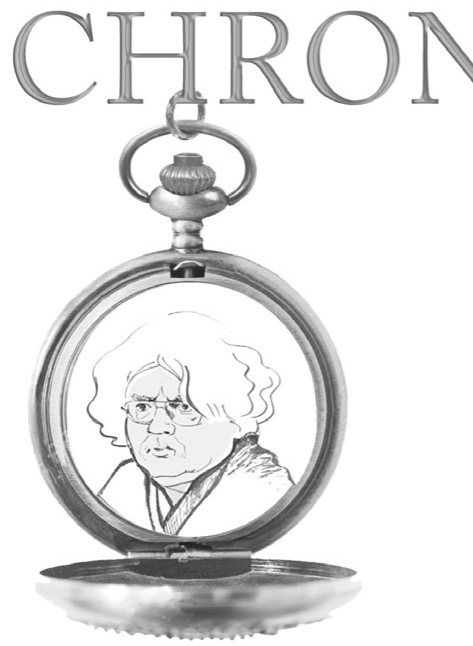

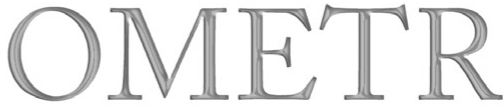

Autorska rubryka prof. UKSW Jana Zielińskiego. Stopniowa prezentacja wybranych wątków szeroko zakrojonego projektu, który ma przedstawić w układzie chronologicznym obecność motywu czasu

i zegara w kulturze polskiej (na tle międzynarodowym) od średniowiecza do XXI wieku. Punktem wyjścia jest przeważnie tekst literacki, ale odniesienia sięgają różnych dziedzin kultury (łącznie z kulturą materialną), historii, etnografii, filozofii. Poszczególne teksty, zbudowane z segmentów ułożonych na ogół chronologicznie, pokazują odrębne zagadnienie - czasem zaskakujące, czasem wręcz paradoksalne - w różnych jego aspektach.

Chciałbym opowiedzieć o dziejach pewnego zegarka, który służył dwóm wielkim Polakom - generałowi Józefowi Bemowi i poecie Adamowi Mickiewiczowi. I o przywiązanej do tego zegarka zupełnie nieznanej pieczęci, zaprojektowanej przez poetę, a przeznaczonej dla polskich wojsk formowanych w Turcji. Będzie to opowieść jeszcze niekompletna, wstępna czekający na uzupełnienia i dopowiedzenia rekonesans. Przedstawione w niej przedmioty są jednak tak niezwykłe, że wręcz domagają się opublikowania.

Punktem wyjścia niechaj będzie krótki, mieszczący się na dwóch stronicach, rękopis przechowywany w Ossolineum. Jego opis według inwentarza rękopisów tej placówki brzmi: „23. Oświadczenie Bolesława Rusieckiego, 
malarza z Wilna, z 1858 r. w sprawie losów zegarka Adama Mickiewicza, ofiarowanego na krótko przed śmiercią prawdopodobnie Tyszce, i odpis oświadczenia Sadyka Paszy (Michał Czaykowski) z 1856 r. dot. przekazywania przez A. Mickiewicza pamiątek po sobie s. 89-92, na s. 90 wizerunek tureckiego medalika, na s. 91 zegarka, z objaśnieniami, wykonane przez B. Rusieckiego"1.

Zacznijmy od zawartości zapisanych kart tego rękopisu, opatrzonego sygnaturą 14600:

[k. 90]

Było to w Rzymie w R[oku] 1858, w drugiej połowie. Poznałem się z przełożonym O[jców] Kapucynów na Piazza Barberini. Pewnego razu będąc u przełożonego, wezwał do siebie i zarekomendował mi dwóch Polaków. Jeden starszy Braciszek z tęgą brodą, urody miernej, czerwstwy[!], świeży, zdrów, lat do 30. Drugi młody. Kleryk (aspirant), lat do 20. Oba dobrze pięknie mówią po polsku. Ze starszym widywałem się częściej, bo ten i u mnie bywał; przy bliższym poznaniu się przyniósł kiedyś do mnie, jakby w lokatę, zegarek ten, jakby czyjąś własność. Opowiadał mi dużo o Wschodzie, o Kozakach polskich w Turcji, o Sadyku Paszy, o Mickiewiczu i wiele, wiele rzeczy i stosunków - pokazał mi mały szkicek (aquarella) pośmiertny Mickiewicza, ze znajomością rzucony. Ze wszystkiego pozwalał mi porobić kopie - Zegarek zdaje się, że chciałby zbyć, ale jako kosztowną pamiątkę - Wszystko jednak, co rozważałem, pozwalało mi przypuszczać, że te rzeczy są w pierwszym ręku i że ten Braciszek musi być jednym z tych, co byli bliżej przy ś[więtej] p[amięci] Mickiewiczu lub przy Sadyku. - Dokument Sadyka Paszy świadczący o pochodzeniu zegarka przepisałem dokładnie, zrobiłem nawet podobiznę podpisu, przyswajając starannie przez szkło. Zegarek skopiowałem tej samej wielkości, co w naturze, ze wszystkimi szczegółami i największą dokładnością. Pieczęć, sznurek, wszystko wierne. - Szkicek pośmiertny Adama tej samej wielkości i bardzo trafny. (Sądzę, że to może być pierwszy po Zgonie Ś[więtej] P[amięci] Adama). Nawet skopiowałem turecki medalik i lentę z natury, bo to wszystko z jednych rąk pochodziło i miało cechę wzajemnego związku z sobą, co do Epoki, chwili - i stosunków etc. etc. W następstwie, okolicznoście[!], jakie zaszły, bardziej wzmocniły mnie w domysłach, że

${ }^{1}$ Inwentarz rękopisów Biblioteki Zakładu Narodowego im. Ossolińskich we Wrocławiu: Rękopisy 14181-14600, opr. Ł. Częścik, red. A. Fastnacht, Wrocław 1979, s. 301. 
ów Braciszek Kapucyn mógł być p[anem] Tyszko - Rzeczy te wszystkie po niejakim czasie zabrał - i wkrótce potem już się z nim więcej nigdzie nie spotkałem - Przy skopiowanych przedmiotach umieszczam szczegółowe i potrzebne objaśnienia.

[monogram zawijany:] B[olesław] Rus[iecki]

Podobizna (Facsimile) wykonane

przez Bolesława Rusieckiego.

Dar Bolesława Rusieckiego

Artysty-Malarza z Wilna.

[obok napisu monochromatyczny rysunek dwóch stron tureckiego medalu, poniżej akwarela przedstawiajaca fragment dwubarwnej wstęgi orderowej]

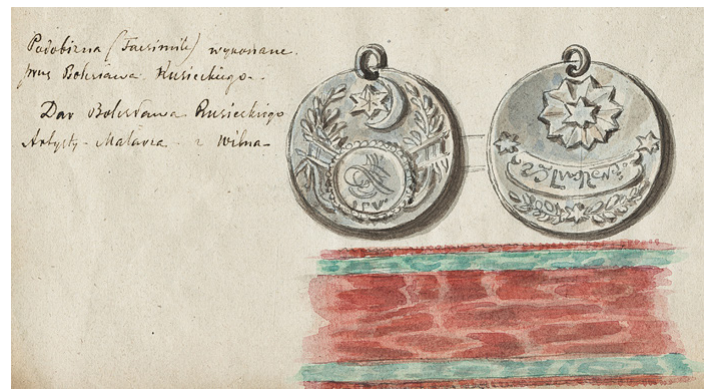

[k. 91]

$\mathrm{Na}$ arkuszu papieru sinawym, taki jak listowy. Cały własnoręcznie pisany i podpisany przez Sadyka Paszy[!].

Kopia. Zgasły 15 listopada 1855 r[oku] w Stambule wielki nasz Adam Mickiewicz przed skonem rozdał tym, którzy go do ostatniej nie odstępowali chwili, wszystko to, co było Jego własnością na wschodzie. Któż nie zna nieodstępnego towarzysza naszego Mistrza, P[ana] Henryka Służalskiego? Który wyjechawszy z nim z Paryża, już go więcej nie odstąpił do samej śmierci i po śmierci nawet zwłoki Jego zwiózł do Paryża. Resztę skromnej eskorty ś[więtej] p[amięci] Mickiewicza składali P[an] Tyszka i pewien starozakonny Hernstejn, znany ze swojego sprytu i Kozackiego ducha. Chociaż wszystkie utensylia Jego nosiły cechę prostoty, potrzeby, a nigdy wygódek, jeden każden coś dostał na pamiątkę, co jako drogi skarb swej przekaże potomności. Z tego źródła i znany powszechnie mały zegarek z pieskiem, który 
jest podwójną pamiątką, bo od Generała Bema dostał się ś[więtej] p[amięci] Mickiewiczowi, przeszedł z udziału do P[ana] Tyszki, autentyczność którego jako przytomny temu aktowi poświadczam - Stambuł, 8 Sierpnia 1856 r[oku]. [podobizna autografu:] Mehmed Sadyk Pasza

Facsimile zegarka, który przy zgonie ofiarował Adam Mickiewicz p[anu] Tyszce jako jednemu z towarzyszy wyprawy do Konstantynopola 1855 r[oku] 15 Listopada.

Objaśnienie:

Zegarek srebrny - Piesek, emalija czarna na złotym dnie. Na kopercie pod pieskiem do góry - L6. Na dolnej kopercie M0109M. / 716. / M.

Pieczęć z laku czerwona. Sznurek prosty bawełniany, różowy.

[monogram zawijany:] B[olesław] Rus[iecki]

N. 1846

Facsimile wykonał Bolesław Rusiecki Artysta-Malarz z Wilna.

[obok kolorowany rysunek czerwonej pieczęci z orłem, umocowanej sznurkiem do ucha narysowanego obok zegarka kieszonkowego z motywem biegnacego pieska na kopercie]

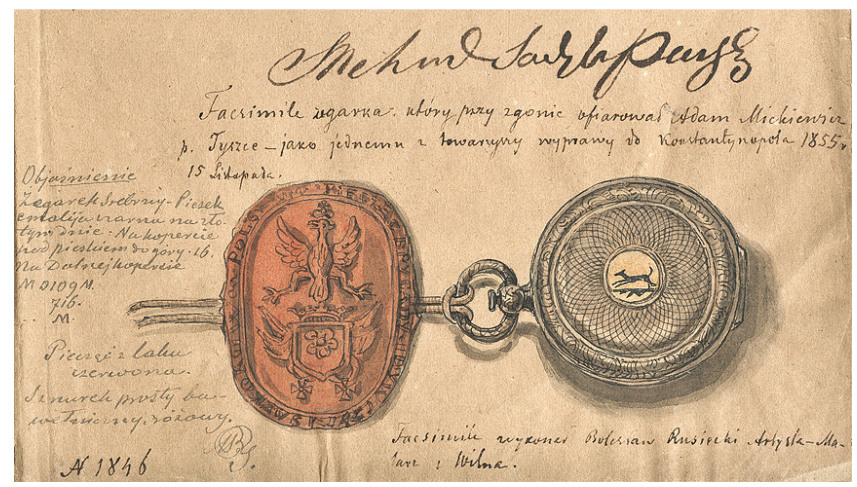

Tyle rękopis. Jego autor, Bolesław Michał Rusiecki, urodził się w roku 1824 w Rzymie, gdzie jego ojciec, malarz wileński Kanuty Rusiecki (1800-1860), przebywał z rekomendacji księcia Adam Czartoryskiego, ucząc się u takich znakomitości, jak Vincenzo Camuccini, Bertel Thorvaldsen i Antoine-Jean Gross. W roku 1832 jego ojciec sportretował go na obrazie Święty Jan Chrzciciel z barankiem (podobnie jak Mickiewicza sportretował jako Jana Chrzciciela na malowanym w latach 30. w Rzymie Chrzcie w Jordanie 
Wojciech Korneli Stattler, późniejszy autor Machabeuszów). W roku 1829 lub 1831 Rusieccy przenieśli się do Wilna, gdzie Bolesław uczył się w Instytucie Szlacheckim, a u wykładającego w tym zakładzie ojca pobierał nauki rysunku. Potem w Petersburgu studiował medycynę i malarstwo (u Fiodora Bruniego i Karła Briułłowa). Współpracował z „Rocznikiem Literackim” Romualda Podbereskiego, który w numerze z roku 1844 ogłosił artykuł o jego ojcu (o wspomnianym obrazie napisał: „zaleca się poprawnością rysunku, dobrze utrzymanym kolorytem oraz nader naturalnym wyrazem twarzy"2). W roku 1854 Bolesław Rusiecki wyruszył w kilkuletnią podróż po Europie, w trakcie której dłużej zatrzymał się w mieście swego urodzenia. Wtedy powstał interesujący nas rękopis.

Dokument ten, publikowany tutaj po raz pierwszy ${ }^{3}$, nie jest zupełnie nieznany. Uwzględnia go Ksenia Kostenicz w kronice ostatnich lat życia Mickiewicza, cytując fragmentarycznie katalog Méyeta: „W r. 1858 malarz wileński Bolesław Rusiecki poznał w Rzymie u przełożonego oo. kapucynów na Piazza Barberini starszego braciszka, Polaka, wieku lat 30, który mu pokazywał zegarek otrzymany od Mickiewicza i [...] akwarelkę (1), a nadto list Sadyka Paszy potwierdzający autentyczność zegarka. Rusiecki przypuszcza, że braciszkiem tym był Tyszko, będący blisko osoby Mickiewicza i Sadyka Paszy”, a w przypisku precyzując: „Akwarela przedstawiała Mickiewicza na łożu śmierci i siedzącego u stóp poety Henryka Służalskiego. Rysunek powstał być może w końcu listopada"s.

Zacytowany fragment Wizerunków A. Mickiewicza dotyczy akwareli opisanej jako pozycja 49: „Tyszko (?) Mickiewicz po skonaniu na łożu śmiertelnym, u stóp jego Henryk Stużalski w postawie siedzacej. O[ryginał]". Autorka Ostatnich lat Mickiewicza, cytując opis Méyeta, pominęła słówko

2 Rld Podb. [Romuald Podbereski], Kilka słów o Kanutym Rusieckim, malarzu w Wilnie, „Rocznik Literacki” 1844, s. 193.

3 Za grzecznościową zgodę na publikację w „Załączniku Kulturoznawczym” podziękowanie zechce przyjąć wicedyrektor Zakładu Naukowego im. Ossolińskich we Wrocławiu, dr Mariusz Dworsatschek.

4 K. Kostenicz, Ostatnie lata Mickiewicza: styczeń 1850 - 26 listopada 1855, Warszawa 1978, s. 454.

5 Ibidem. Ów „rysunek akwarelą o. Tyszki” jest też wzmiankowany na stronie $528 \mathrm{w}$ tej samej pozycji. 


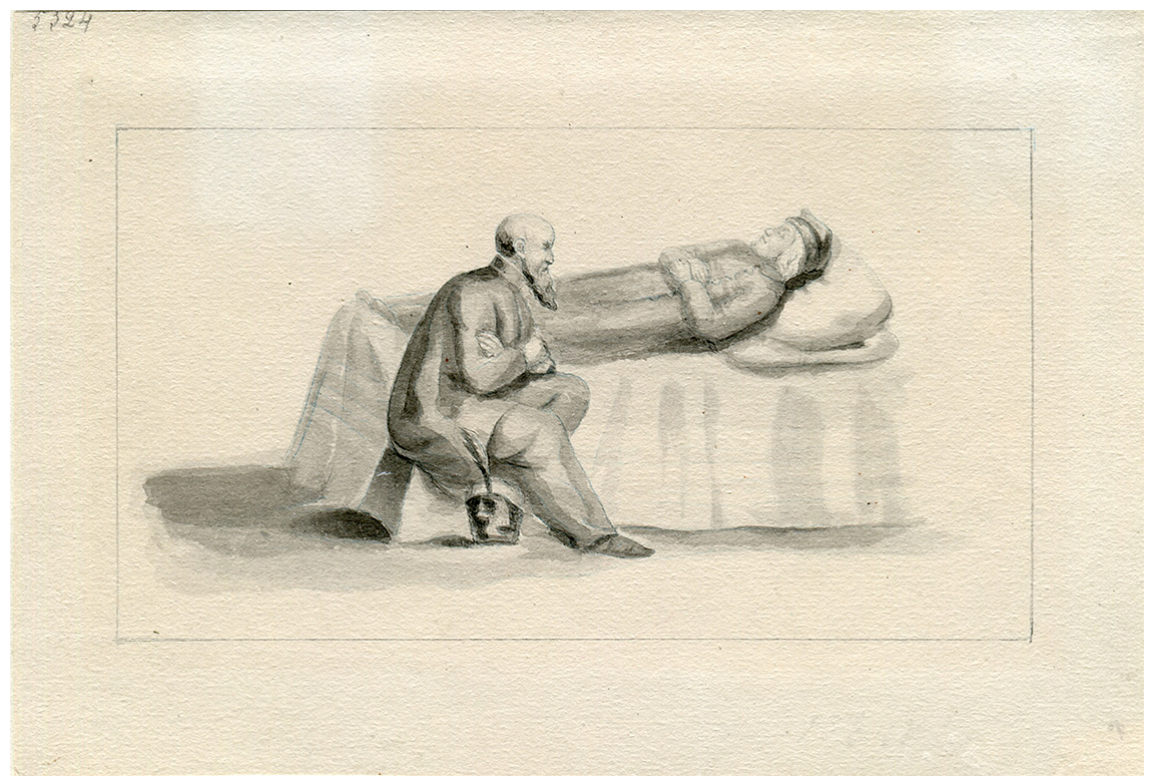

Tyszka? Tyszko?, Adam Mickiewicz na łożu śmierci (obok siedzi Henryk Służalski), Muzeum Literatury im. Adama Mickiewicza w Warszawie

„powyższą [akwarelkę]” i zdanie: „Wierna kopia z powyższej akwareli, sporządzona przez Rusieckiego, znajduje się w zbiorach muzealnych Zakładu Ossolińskich we Lwowie"6. Ponadto w dziale Fototypy katalogu Méyeta znajduje się jako pozycja 130: „Mickiewicz na łożu śmiertelnym, według akwareli Tyszki. 68x13 mil[imetrów]. K[opia]"7. Adnotacja o proweniencji odsyła do strony 33 Albumu pamiątkowego Adama Mickiewicza Bełzy (skrupulatny Méyet podaje też, że fototypia ta została wytrawiona w Pradze w zakładzie Husznika \& Häuslera ${ }^{8}$ ).

W zbiorach warszawskiego Muzeum Literatury im. Adama Mickiewicza znajduje się praca (sygn. ML K874) opisana jako: „Tyszka? Tyszko? Adam Mickiewicz na łożu śmierci (obok siedzi Henryk Służalski). 11x16. Ołówek,

${ }^{6}$ L. Méyet, Wizerunki A. Mickiewicza. Uzupetnienie, Lwów 1889, s. 11.

7 Ibidem, s. 25.

8 Ibidem. Zob. W. Piast [Władysław Bełza], Album pamiątkowe Adama Mickiewicza, Lwów 1889, s. 33: Mickiewicz na łożu śmiertelnym. 
tusz, papier”. Wedle zapisu w księdze inwentarzowej Działu Sztuki jej proweniencja była następująca: „Ze zbiorów L. Méyeta przekazanych przez Muzeum Narodowe w Warszawie 3 VII 1953" 9 . Reprodukcję tej pracy zamieścił Stanisław Rosiek w książce o agonii i śmierci Mickiewicza ${ }^{10}$.

W publikowanym tutaj rękopisie Rusieckiego ze zbiorów Ossolineum są rysunki medalu, zegarka i pieczęci, nie ma natomiast wykonanej przez niego, jak wynika z tekstu, kopii akwareli Tyszki. Czyżby trafiła ona do zbiorów zagorzałego kolekcjonera Méyeta już po opublikowaniu jego katalogu wraz z uzupełnieniami, a ze zbiorów owych, z czasem, do Muzeum Literatury?

Spośród wymienionych w rękopisie osób objaśnienia nie wymagają ani Mickiewicz, ani Bem, ani Michał Czajkowski - Sadyk Pasza. Mniej znany jest Henryk Służalski, ale i on doczekał się biogramu (pióra samego Stefana Kieniewicza) w Polskim Słowniku Biograficznym. Pozostają dwa nazwiska: Tyszko i Hernstejn.

Tyszko funkcjonuje na obrzeżach mickiewiczologii jako „Tyszko”, samo nazwisko bez imienia. W cytowanej już kronice Kseni Kostenicz pod datami ramowymi 22.09-26.11.1855 jest lakoniczny zapis: „Konstantynopol albo Burgas. Spotkania Mickiewicza z o[jcem] Tyszko?"11, wsparty znanym nam już cytatem z katalogu Méyeta.

W kontekście rękopisu Rusieckiego warto wskazać na związki rzymskich kapucynów z Polską, zwłaszcza z Łomżą. Od roku 1819 w klasztorze w Łomży mieszkał prowincjał krakowski Filip z Szumowa (o. Kalikst Szumowski, 1775-1851), który w roku 1824 został mianowany przez papieża Leona XII prokuratorem generalnym kapucynów w Rzymie. Szumowski przywiózł raport biskupa Jana Pawła Woronicza na temat sytuacji Kościoła w Polsce, który przełożył na łacinę i opatrzył własnymi komentarzami. Po kilku latach wrócił do kraju ze względu na stan zdrowia, ale do końca życia „był łącznikiem między polską prowincją kapucynów a naczelnymi

9 Za informacje te dziękuję kustosz Muzeum Literatury, Marii Dorocie Pieńkowskiej.

10 Tyszko, Stużalski siedzący u stóp zmarłego poety, [w:] Stanisław Rosiek, Zwłoki Mickiewicza. Próba nekrografii poety, Gdańsk 1997, s. 15.

${ }^{11}$ K. Kostenicz, op. cit., s. 454. 
władzami zakonu"12. Natomiast od roku 1814 przełożonym klasztoru kapucynów w Łomży był Jerzy z Duchn Starych, który w roku 1821 zapisał, iż „W okresie siedmiu lat jego przełożeństwa przygotowano w klasztorze do chrztu 32 Żydów"13. Ojciec Jerzy w życiu cywilnym nazywał się Dominik Tyszka ${ }^{14}$. Oczywiście, obaj wspomniani zakonnicy zmarli przed rokiem 1858, ale można sobie wyobrazić, że jakiś krewny Jerzego z Duchn za protekcją Filipa z Szumowa dostał się do rzymskiego klasztoru przy Piazza Barberini. Potwierdzenie takiej hipotezy znaleźć można u Ewy Jabłońskiej-Deptuły, która pisze:

W zasięgu oddziaływania konwentu łomżyńskiego spotykamy całe „zagłębie” powołań kapucyńskich. Wielu kandydatów dostarczyły te same wsie szlacheckie, np. Duchny, Olszewo, Mieszki, powtarzają się również zgłoszenia z tych samych rodzin. Oto kilka przykładów. Funkcję katechety szkoły łomżyńskiej i tamtejszego gwardiana oraz mistrza nowicjatu pełnił przez długi czas jeden z bardziej zasłużonych kierowników prowincji o. Jerzy Tyszka. Oprócz o. Jerzego - późniejszego prowincjała - wstąpiło do kapucynów w I poł. XIX w. 3 innych jeszcze Tyszków: w 1813 r. - Kalikst Tyszka oraz dwóch nowicjuszy: w 1833 r. - Narcyz Tyszka, a w 1826 r. - August Tyszka. Wszyscy wymienieni pochodzili z łomżyńskiego Olszewa ${ }^{15}$.

Z trzech wymienionych co najmniej dwaj dożyli powstania styczniowego - jeden z nich mógł zatem być w roku 1855 w Konstantynopolu, a trzy lata później w Rzymie. Do wahań w pisowni nazwiska (Tyszka/ Tyszko) nie trzeba przywiązywać nadmiernej wagi; w samym rękopisie

12 A. Barańska, Między Warszawa, Petersburgiem i Rzymem. Kościół a państwo w dobie Królestwa Polskiego (1815-1830), Lublin 2008, s. 693.

${ }^{13}$ H. Sierzputowski, Kapucyni. Klasztor i kościół, Serwis Historyczny Ziemi Łomżyńskiej, http://historialomzy.pl/klasztor-i-kosciol-braci-mniejszych-kapucynow/ [dostęp: 2.08.18].

14 „O. Jerzy, Dominik Tyszka, ur. 4 VIII 1774 r. w Duchnach Starych, do zakonu wstąpił 14 IV 1795 r. w Lubartowie, zm. 4 III 1836 r. w Nowym Mieście”. H.D. Wojtyska CP, Katalog rękopisów Biblioteki Seminarium Duchownego w Lublinie (dok.), „Archiwa, Biblioteki i Muzea Kościelne” 1975, t. 30, s. 140.

15 E. Jabłońska-Deptuła, Przystosowanie i opór. Zakony męskie w Królestwie Kongresowym, Warszawa 1983, s. 234. 
Rusieckiego w tekście autorskim pojawia się forma „Tyszko”, a w odpisie z Sadyka Paszy - „Tyszka”.

„Starozakonny Hernstejn” przewija się przez wspomnienia Czajkowskiego i przez przedwojenną książkę Romana Brandstaettera o Mickiewiczowskim Legionie Żydowskim. Oto pierwszy cytat z Czajkowskiego:

Pan Armand Levy, Izraelita francuski, przyjaciel i towarzysz Adama Mickiewicza na Wschodzie, przywiózł mi do Szumny bogi żydowskie, Talmud, żydowskie księgi, koszule, jak je zowią, śmiertelne, suknie i ogromną ilość pak ze sprzętami religijnymi. Wszystko było warte najmniej pięćdziesiąt tysięcy franków, dar bogaty, zwyczajnie dar jednego z rodziny królewskiej finansów. Przy tym był model munduru, spodnie czekoladowego koloru, mantyl żółty, dolman czekoladowy, a wszystko szamerowane złotem. Był to gest młodego Rotszylda. Adam Mickiewicz żartując mówił p. Zamoyskiemu, że to były barwy kapucynów i bernardynów, a zatem oznaki zbliżenia się judaizmu do katolicyzmu ${ }^{16}$.

Żart Mickiewicza stanowi zarazem dobry pomost między narracją o kapucynach na Piazza Barberini a opowieścią o starozakonnym Hernsztejnie. A oto drugi cytat ze wspomnień Czajkowskiego:

Cholera grasowała w Konstantynopolu, Adam Mickiewicz czuł się nie bardzo dobrze. Kozak Służalski na lekarstwo sporządził mu kaczkę duszoną i wysadzoną kwaszoną kapustą, potrawę sybirską Jermaka. Moszko Horenstein, huzar izraelski z Murowanej Machnówki, będący takoż przy A. Mickiewiczu, na tę biesiadę higieniczną przyniósł pierożków berdyczowskich i butelkę miodu chodorkowskiego. Po biesiadzie nastąpił atak piorunujący cholery. Wydał wśród bólów rozkazy Bednarczykowi, Horensteinowi, wypowiedział ostatnią wolę Służalskiemu ${ }^{17}$.

Barwne szczegóły kulinarne można pewnie złożyć na karb wybujałej fantazji Czajkowskiego, ważne jest potwierdzenie przebywania Horensteina w pobliżu Mickiewicza w ostatnim okresie życia poety (trzeba tu zresztą

16 M. Czajkowski, Moje wspomnienia o wojnie 1854 roku, opr. J. Fijałek. Warszawa 1962, s. 250-251.

17 Ibidem, s. 251. 
zaznaczyć, że zarówno Ksenia Kostenicz, jak i Stanisław Rosiek nie wymieniają go wśród ośmiu osób, które były przy Mickiewiczu w chwili jego śmierci $\left.{ }^{18}\right)$.

Brandstaetter pisze o nim:

Michał Horenstein, chorąży, a potem podporucznik II pułku kozaków ottomańskich. Przeniesiony do I pułku w randze porucznika. Za zasługi u boku Mickiewicza wyniesiony do rangi kapitana [...]. Ulubieniec Mickiewicza i Śniadeckiej. [...] W czasie pobytu Mickiewicza w Konstantynopolu sprawował przy nim obowiązki adiutanta. Horenstein był dobrym Żydem, posiadał duże poczucie narodowe, krystalicznie czysty charakter i odznaczał się wielką odwagą. Za dzielne sprawowanie się na polu bitwy otrzymał medal waleczności. Po wojnie krymskiej zaciągnął się do armii tureckiej. Zmarł nagle w r. 1868 na pokładzie statku zdążającego z Konstantynopola do Warny ${ }^{19}$.

To charakterystyka ogólna zamieszczona w przypisie. Podaje ona fakty biograficzne, elementy oceny. Dla naszej opowieści ważniejszy jest natomiast fragment, w którym Brandstaetter, sięgając po inny rękopiśmienny tekst Czajkowskiego, kreśli ostatnie dni życia poety:

W chwilach, gdy stan zdrowia Mickiewicza poprawiał się, długo rozmawiał na temat przyszłej organizacji legionu z ulubieńcem swoim porucznikiem Horensteinem, to znów żartował z niego, oglądając oczyma już mgłą zachodzącymi jasne uniformy żydowskiego pułku, w które odświętnie przybrali się Horenstein i jego młody przyjaciel, Żyd hiszpański - De Castro. Pisze o tej chwili Czaykowski: „Żartował z Horensteina, że ten już przebrał się w mundur huzarów Izraela i że przybrał w taki sam ubiór swego młodego przyjaciela De Castro. Goliaty, Samsony, Holofernesy (mówił Mickiewicz), tylko patrzcie, żeby wam jaka Judyta lub Delila w drogę nie wlazła, bo połamie wszystkie szyki i z huzarów Izraela trzeba będzie znów iść na faktorów, na geszeft"20.

18 Zob. K. Kostenicz, op. cit., s. 518; S. Rosiek, op. cit., s. 138 i 301.

19 R. Brandstaetter, Legion żydowski Adama Mickiewicza (dzieje i dokumenty), Warszawa 1932, s. 64-65.

20 Ibidem, s. 35-36. Cytat z Czajkowskiego: Mickiewicz w obozie kozackim, rękopis nr 876 ze zbiorów ówczesnego Muzeum Mickiewiczowskiego w Paryżu. 
Maria Janion, komentując to miejsce, napisze:

Mickiewicz nie umiał, a może i nie chciał, powstrzymać się od czasu do czasu od dość powszechnych w kulturze polskiej żartów na tematy żydowskie - komicznego kontrastu przeciwstawiającego dzielnych żołnierzy - bojaźliwym cywilom ${ }^{21}$.

Zapewne. Ale od żartów narodowościowych istotniejszy jest tu chyba aspekt genderowy, motyw przebierania się w barwne, fantazyjne mundury, kreowania kolorowej maskarady. Dojrzały Mickiewicz przestrzegał przed konfrontacją takich zapałów, przed ich zetknięciem się z życiowymi realiami.

Przerysowany przez Rusieckiego ,turecki medalik” wraz ze wstęgą (lentą) to zapewne jeden $\mathrm{z}$ medali Medżidże (wedle dzisiejszej terminologii: order medżydżów), o których Czajkowski pisze:

Odebrałem rozkaz udania się do Szumni z Kozakami, gdzie nam dano medale za kampanię dunajską z obrony Silistrii, czterdzieści pięć Medżidże czwartej i piątej klasy dla oficerów i żołnierzy z Kozaków [...]. Liczba Kozaków w dziewięciu szwadronach była tysiąc i sześćset jeźdźców. Medalów z patentami do wpisania imion było dwa tysiące. Polaków w Kozakach było czterystu ${ }^{22}$.

Wstęga rzeczywiście odpowiada barwom i szerokości wstęgi tego, przyznawanego od 29 sierpnia 1852 roku, tureckiego odznaczenia wojskowego. Konfrontacja z monograficznym albumem takich odznaczeń nie pozwoliła na ustalenie, jakiej dokładnie klasy order został przedstawiony na rysunku Rusieckiego $^{23}$. Zdaje się wszakże nie ulegać wątpliwości, że nie był to medalik, tylko cesarski order za waleczność, przyznany w początkowym okresie jego istnienia (pod koniec państwa otomańskiego wartość medalu bardzo się zdewaluowała).

Jeśli chodzi o narysowany i opisany przez Rusieckiego zegarek, to choć jego nazwa nie pada w tekście, nasuwa się domniemanie, że mamy do czynienia z wyrobem firmy Patek, na której czele stał Polak i która wśród swych

${ }^{21}$ M. Janion, Bohater, spisek, śmierć. Wykłady żydowskie, Warszawa 2009, s. 228.

22 M. Czajkowski, op. cit., s. 255.

${ }^{23}$ Zob. I. Artuk, C. Artuk, Osmanlı nişanları. Istanbul 1967, passim. 
klientów miała wielu Polaków. W dwutomowym katalogu genewskiego Musée Patek Philippe jest cały rozdział poświęcony zegarkom z motywami zwierzęcymi i przyrodniczymi. Najbardziej zbliżony do naszego jest zegarek nr 3009, produkowany w latach 1848-1850, ze wzorem z czarnej emalii na tylnej kopercie, przedstawiającym dwa charty angielskie ${ }^{24}$.

Trzeba tu przypomnieć, że Norbert Patek służył pod rozkazami Bema, który po powstaniu listopadowym powierzył mu zorganizowanie punktu opieki nad polskimi wychodźcami w Bambergu ${ }^{25}$. Znał też osobiście Mickiewicza i pośredniczył w jego korespondencji, korzystając z położenia Genewy na pograniczu szwajcarsko-francuskim. Zarówno postać Bema, jak i Mickiewicza stanowiły też motywy przedstawiane na zegarkach Patka. Jak pisze Wanda Bigoszewska, wyroby firm Czapek i Spółka oraz Patek-Philippe:

nosiły wizerunki polskich bohaterów narodowych, najczęściej Tadeusza Kościuszki, ks. Józefa Poniatowskiego, generała Józefa Sowińskiego, ge ne rała Józefa Bema, a później Adama Mickiewicza i Jana Matejki. Częstym motywem zegarków Patka i Czapka były wizerunki Matki Boskiej Częstochowskiej i Matki Boskiej Ostrobramskiej oraz herb dwupolowy Polski i Litwy. Zegarki wykonywano najczęściej w złocie, często różnobarwnym or aux quatre couleurs, czasem, a właściwie sporadycznie, w srebrze. Zdobiono je barwną emalią, grawerowaniem lub cyzelowaniem ${ }^{26}$.

Wprawdzie w liście z 8 marca 1849 roku Patek dementował krążące po Paryżu pogłoski, jakoby to on „był upoważniony i posiadał niezbędne środki w celu sformowania legionu polskiego we Włoszech"27, ale mogło to być dementi taktyczne. A był przy tworzeniu legionów we Włoszech obecny w sposób symboliczny. Jak pisze Alina Witkowska:

${ }^{24}$ Zob. Patek Philippe watches, t. 1, Genève 2013, s. 130 (rozdział: Animal and Nature-Themed Watches, 1846-1871).

25 Polski słownik biograficzny, t. XXV, Kraków - Wrocław 1980, s. 320 (autorka hasła: Halina Florkowska-Frančić).

26 W. Bigoszewska, Polska biżuteria patriotyczna, Warszawa 2003, s. 75-76; podkreśl. J.Z.

27 „Journal de Genève”, wydanie z dnia 13 marca 1849 r., s. 2. 
Gdy trzeba było godło narodowe umieścić na drzewcu, zabrakło pieniędzy na zrobienie orła i poeta oderwał kopertę od pamiątkowego zegarka słynnej później firmy Patek, na której wyryty był orzeł, przybił go do kija - i tak powstało godło ${ }^{28}$.

Hipoteza, iż chodzi o zegarek Patka, nie znajduje jednak potwierdzenia $w$ archiwach firmy. $\mathrm{Z}$ informacji udzielonych uprzejmie przez archiwistkę muzeum Patek Philippe, panią Flavię Ramelli, wynika, że zegarek Patka nr 1846 nie został ofiarowany ani sprzedany generałowi Bemowi, nie zgadza się też opis tego zegarka $w$ archiwach firmy z rysunkiem i opisem Rusieckiego. Ponadto ani spółka Patek Philippe, ani Patek Czapek praktycznie nie używały srebra do wytwarzania kopert. Również litery i cyfry zanotowane przez Rusieckiego nie wskazują na wyrób Patka ${ }^{29}$.

W tej sytuacji należy skierować poszukiwania w innym kierunku. Może producentem opisanego zegarka był Franciszek Czapek po rozstaniu się z Patkiem? A może inny zegarmistrz, niekoniecznie polskiego pochodzenia. Poszukiwania trwają.

$\mathrm{Na}$ rysunku Rusieckiego do ucha zegarka umocowana jest sznurkiem czerwona pieczęć lakowa. To chyba największa rewelacja omawianego rękopisu - chodzi bowiem o wizerunek pieczęci zaprojektowanej przez Mickiewicza z myślą o legionie żydowskim lub innym oddziale wojsk polskich formowanych w roku 1855 w obrębie armii tureckiej. Świadczy o tym zarówno napis w otoku pieczęci, jak i jej wnętrze. Napis w otoku głosi: „PIECZEĆ́ BRYGADY I DYWIZJI [słowo nieczytelne] POLSKICH”.

Rusiecki w ogóle nie porusza kwestii napisu, ponieważ jednak większość odwzorowanych przez niego liter napisu na pieczęci jest bardzo wyraźna, można domniemywać, że w miejscu przedostatniego słowa litery lakowego odcisku były zamazane. Najprawdopodobniej brakujące słowo jest rzeczownikiem w dopełniaczu liczby mnogiej, oznaczającym rodzaj formacji bądź jej pochodzenie - w grę mogły wchodzić, w kolejności alfabetycznej, słowa: „dragonów”, „husarów”, „kozaków”, „ułanów”, „żuawów”30, albo

28 A. Witkowska. Mickiewicz. Słowo i czyn, Warszawa 1975, s. 273.

29 Flavia Ramelli, maile do autora z dnia 11 czerwca 2018 r.

30 Dobrym źródłem potencjalnych nazw formacji jest artykuł Krzysztofa Karbownika: Polskie formacje zbrojne $w$ armii tureckiej $w$ wojnie krymskiej 1853-1856, „Przegląd Wojskowo-Historyczny” 2012, nr 4, s. 215-233. 
też: „Izraelitów”, „Machabeuszów”, „Żydów”. Żadne z nich jednak całkiem nie zgadza się z przerysem. Być może ostatnie słowo napisu należy czytać jako „POLSKIEJ” lub „POLSKIEGO” (końcówka nie jest całkiem wyraźna), wówczas przedostatnim słowem mogłoby być: „husarii”, ,jazdy”, „hufca”, „korpusu” lub „legionu”. I te propozycje nie znajdują jednak pełnego potwierdzenia.

W górnej pieczęci znajduje się wizerunek orła z rozpostartymi skrzydłami i łapami, w dolnej zaś umieszczony został herb Mickiewiczów, Poraj, w tarczy ozdobionej u spodu dwoma krzyżami, z mitrą książęcą. Najprawdopodobniej orzeł został niejako wmontowany w górne obramowanie tarczy, między samą mitrę a wieńczący ją krzyż.

Patrząc na tę pieczęć, trudno oprzeć się skojarzeniu z pieczęcią, jaką posługiwał się niekiedy - wobec wybranych osób - pod koniec życia inny polski poeta. Była ona opatrzona napisem: „Dowódca Królewskiej / Samodzielnej Brygady Huzarów Śmierci - Pułkownik Zbigniew Herbert”’31. Siostrzeniec Herberta, Rafał Żebrowski, w artykule na temat tej pieczęci i jej symboliki sięga między innymi do żuawów śmierci - oddziałów, które zdobyły rozgłos w trakcie wojny krymskiej, i podkreśla orientalne motywy umundurowania żuawów: „W służbie Francji przywdziewali oni bufiaste szarawary w kolorze czerwonym i białe turbany. Polscy żuawi również nosili szarawary (szeregowcy zielone, oficerowie czerwone), fezy, czarne sukienne surduty, a ich kamizelki zdobił duży biały krzyż naszywany na czarnym tle"32. Retoryka wojskowa kwitła też w korespondencji Herberta z młodszym poetą Januszem Szubertem, zapoczątkowanej listem z końca

${ }^{31}$ Taką pieczęcią opatrzył między innymi dedykację na podpisanym na Wielkanoc roku 1997 dla Tadeusza Chrzanowskiego egzemplarzu drugiego wydania tomu Hermes, pies i gwiazda (Wrocław 1997). Z. Herbert, T. Chrzanowski, „Mój bliźni, mój bracie” Listy 1950-1996, Kraków 2016, s. 319. Tą samą pieczątką podstemplowany został egzemplarz tekstu Cień jaskółki. Esej o myślach Chopina, przesłany Magdalenie i Zbigniewowi Czajkowskim. Zob. Wierność. Wspomnienia o Zbigniewie Herbercie, opr. A. Romaniuk. Warszawa 2014, s. 231.

32 R. Żebrowski, Zbigniew Herbert - dowódca Królewskiej Samodzielnej Brygady Huzarów Śmierci, Oficjalna strona Herbertiady, http://wdq.home.pl/html/herbert/ eseje30.htm [dostęp: 4.06.18]. 
roku 1996 opatrzonym tą właśnie pieczęcią ${ }^{33}$. Herbert oczywiście nie mógł znać pieczęci Mickiewicza, publikowanej tu po raz pierwszy - tym bardziej zastanawiająca jest ta zbieżność.

Poraj na lakowej pieczęci w roku 1855 budzi jeszcze jedno skojarzenie zegarkowe. W roku 1830 poeta był w Genewie. Seweryna Duchińska (której mąż należał do tych ośmiu osób obecnych przy łożu śmierci wieszcza) w opublikowanym w roku 1871 obszernym artykule biograficznym o Mickiewiczu, opartym na relacji Ewy z Ankwiczów, informuje:

W ciągu dwumiesięcznego pobytu w Genewie Adam bywał codziennym gościem w domu hrabiego. Przywiózł on Ewuni mnóstwo drobnych pamiątek zebranych po drodze; miał to być zawiązek przyszłego muzeum. Miedzy innymi były dwa gwoździe z Pompei, maleńki Wezuwiusz w miniaturze, odlany z metalu, i ów odłamek kryształu skalnego z Mont Blanc, o którym wspominaliśmy powyżej.

Ewunia spostrzegła wielką zmianę w jego powierzchowności. Dotąd zaniedbany cokolwiek w ubraniu, teraz nadzwyczaj był staranny, prawie wytworny. W Genewie, kraju zegarmistrzów, kupił piękny zegarek: kazał na nim wyryć herb Poraj, ozdobiony mitrą książęcą. (Mickiewicze mają mitrę w swym herbie).

Oglądali wszyscy ten zegarek, oglądał go i hrabia. Może być, że Adam chciał tym sposobem przypomnieć, że Poraj ma prawo stanąć w parze z Habdankiem ${ }^{34}$.

Po ogłoszeniu artykułu Duchińskiej Edward Odyniec w liście do redakcji prostował między innymi sprawę zegarka z herbem Porajów, pragnąc zatrzeć w czytelnikach wrażenie, jakoby „się Mickiewicz ele ga n tow ał dla Ewuni, albo że kazał wyryć swój herb na zegarku, dla z a i m po now a nia hrabiemu" 35 . Odyniec zacytował odpowiedni fragment relacji Duchińskiej

33 „Dalsza część listu utrzymana była w trybie "nakazowo-rozkazowym», stosowała słownictwo wojskowe, łącznie z instrukcją określającą postępowanie w najbliższej przyszłości [...]”. Janusz Szuber, Wspominki plutonowego, „Kwartalnik Artystyczny" 1999, nr 2, s. 81.

34 [S. Duchinska], Kronika zagraniczna, „Biblioteka Warszawska” 1871, t. I, s. 470 .

35 A.E. Odyniec, Do redakcji „Biblioteki Warszawskiej”, „Biblioteka Warszawska” 1841, t. II, s. 140. 
i oznajmiał, że w słowach tych jest zarazem „i najzupełniejsza prawda, i największa nieprawda; prawda co do samych faktów, nieprawda co do ich znaczenia" 36 . Po czym dodał, że Mickiewicz chciał sobie sprawić nowe ubranie już w Neapolu. Co do czasomierza, po przybyciu poety do Genewy panna Anastazja Chlustin „zajęła się wyborem zegarka u znajomego sobie zegarmistrza" ${ }^{37}$. Wszystko to jednak działo się przed przybyciem państwa Ankwiczów do Genewy:

Co zaś do herbu - ten, zamiast cyfry, doradziła sama panna Anastazja, a wyryty on został podług starej pieczątki, którą Adam miał jako pamiątkę po ojcu i która sama zapewne musiała być podług herbarza. Że mitra mogła zwrócić czyjąś uwagę, nie idzie za tym, ażeby sam Poraj przywiązywał do niej jakie znaczenie, tym bardziej że mitry podobne (nie książęce państwa rzymskiego, ale kniaziowskie) mają herby wielu bardzo rodzin litewskich ${ }^{38}$.

Sprawę podsumował Piotr Chmielowski, pisząc ostrożnie:

Sprawił sobie nowe ubranie, podług spółczesnej mody skrojone, na zegarku kazał wyryć, za radą panny Anastazji Klustin, wtedy już narzeczonej hr. Circourt, mitrę książęcą i herb swój Poraj, który mógł już jako rywal Habdanka (herb państwa Ankwiczów) uchodzić. Czy zmiany te w garderobie miały swe źródło w chęci przypodobania się arystokratycznej pannie (jak twierdzi Duchińska), czy też były czysto przypadkowe (jak utrzymuje Odyniec), trudno oczywiście rozstrzygnąć3 ${ }^{39}$.

Zestawienie tych wszystkich świadectw pozwala wyprowadzić genealogię sporządzonego przez Bolesława Rusieckiego przerysu pieczęci polskiego oddziału wojskowego w Turcji. Najpierw była herbowa pieczątka po zmarłym w roku 1812 ojcu. Z niej kazał Mickiewicz w roku 1830 wyryć w Genewie herb Poraj z mitrą na kopercie zegarka. Następnie, w roku 1848, użył koperty zegarka Patka z motywem orła jako godła na sztandarze

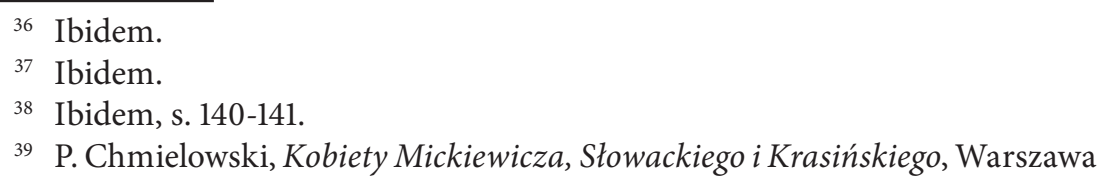
1888, s. 68. 
formowanego we Włoszech legionu. Siedem lat później, w roku 1855, połączył oba motywy - herbu i orła - w wykonanym wkrótce przed śmiercią projekcie pieczęci polskiej formacji na Wschodzie. Pieczątka i herb; herb i zegarek; zegarek i orzeł; orzeł i godło; wreszcie: zegarek z pieskiem oraz pieczęć z herbem i orłem.

\section{Bibliografia}

Ibrahim Artuk, Cevriye Artuk, Osmanlı nişanları, Istanbul Matbaasi, Istanbul 1967. Anna Barańska, Między Warszawą, Petersburgiem i Rzymem. Kościót a państwo w dobie Królestwa-Polskiego (1815-1830), TN KUL, Lublin 2008.

Władysław Bełza, Album pamiątkowe Adama Mickiewicza, Księgarnia Hermana Altenberga, Lwów 1889.

Wanda Bigoszewska, Polska biżuteria patriotyczna, Comandor, Warszawa 2003.

Roman Brandstaetter, Legion żydowski Adama Mickiewicza (dzieje i dokumenty), Menora, Warszawa 1932.

Piotr Chmielowski, Kobiety Mickiewicza, Słowackiego i Krasińskiego, Gebethner i Wolff, Warszawa 1888.

Michał Czajkowski, Moje wspomnienia o wojnie 1854 roku, opr. J. Fijałek, Wydawnictwo MON, Warszawa 1962.

Seweryna Duchinska, Kronika zagraniczna. „Biblioteka Warszawska” 1871, t. I. Zbigniew Herbert, Tadeusz Chrzanowski, „Mój bliźni, mój bracie” Listy 1950-1996, Znak, Kraków 2016.

Inwentarz rękopisów Biblioteki Zakładu Narodowego im. Ossolińskich we Wrocławiu: Rękopisy 14181-14600, opr. Ł. Częścik, red. A. Fastnacht, Ossolineum, Wrocław 1979.

Ewa Jabłońska-Deptuła, Przystosowanie i opór. Zakony męskie w Królestwie Kongresowym, PAX, Warszawa 1983.

Maria Janion, Bohater, spisek, śmierć. Wykłady żydowskie, W.A.B., Warszawa 2009. Krzysztof Karbownika, Polskie formacje zbrojne $w$ armii tureckiej w wojnie krymskiej 1853-56, „Przegląd Wojskowo-Historyczny” 2012, nr 4.

Ksenia Kostenicz, Ostatnie lata Mickiewicza: styczeń 1850 - 26 listopada 1855, PIW, Warszawa 1978.

Leopold Méyet, Wizerunki A. Mickiewicza. Uzupełnienie, Drukarnia E. Winiarza, Lwów 1889. 
Antoni Edward Odyniec, Do redakcji „Biblioteki Warszawskiej”, „Biblioteka Warszawska" 1841.

Romuald Podbereski, Kilka słów o Kanutym Rusieckim, malarzu w Wilnie, „Rocznik Literacki" 1844.

Polski słownik biograficzny, t. XXV, Ossolineum, Kraków - Wrocław 1980.

Anna Romaniuk, Wierność. Wspomnienia o Zbigniewie Herbercie, PWN, Warszawa 2014.

Stanisław Rosiek, Zwłoki Mickiewicza. Próba nekrografii poety, Słowo/Obraz Terytoria, Gdańsk 1997.

Janusz Szuber, Wspominki plutonowego, „Kwartalnik Artystyczny” 1999, nr 2.

Alina Witkowska. Mickiewicz. Słowo i czyn, PWN, Warszawa 1975.

Henryk Damian Wojtysek CP, Katalog rękopisów Biblioteki Seminarium

Duchownego w Lublinie (dok.), „Archiwa, Biblioteki i Muzea Kościelne” 1975.

\section{Źródła internetowe}

Henryk Sierzputowski, Kapucyni. Klasztor i kościół, Serwis Historyczny Ziemi Łomżyńskiej, http://historialomzy.pl/klasztor-i-kosciol-braci-mniejszych -kapucynow/.

Rafał Żebrowski, Zbigniew Herbert - dowódca Królewskiej Samodzielnej Brygady Huzarów Śmierci, Oficjalna strona Herbertiady, http://wdq.home.pl/html/ herbert/eseje30.htm.

\section{Adam Mickiewicz's Watch and Seal}

The article is an analysis of an illustrated note, handwritten in Rome in 1858 by a painter from Wilno, Bolesław Rusiecki,. The note described some objects (a silver watch, a wax seal and an Ottoman medal with a ribbon), owned by a Polish monk named Tyszka or Tyszko, who was supposedly close to Adam Mickiewicz during his final weeks at Constantinople in 1855. The watch is said to belong previously to general Józef Bem, who died at Aleppo in 1850. The most important of these objects seems to be the seal with an inscription (which links it to a military unit of Polish volunteers in Turkey in 1855), a Polish eagle and Mickiewicz's coat of arms - most probably designed by the poet himself on his deathbed.

Keywords: Adam Mickiewicz, Józef Bem, Bolesław Rusiecki, silver watch, wax seal, Ottoman medal, Polish units in Turkey 1855 